\title{
Corrupção e decadência: atualização da morte no folheto de cordel
}

\author{
Linduarte Pereira Rodrigues*
}

\begin{abstract}
Resumo
Duas inquietações movem a curiosidade humana, o lugar de onde viemos e o lugar para onde iremos. Espera-se saber como foi o princípio (cosmogonia), como as coisas começaram a acontecer; e como será o nosso fim (escatologia), o momento que demarca o último dia da humanidade. Este artigo pretende apresentar o resultado de uma pesquisa que visava demonstrar que o cordel, como escritura medieval na contemporaneidade, narra e discursiviza temas que sempre estão presentes na memória social. Nossa pesquisa constatou que os folhetos atualizam, com bastante recorrência, o tema da morte e do fim dos tempos, conectando sujeitos, épocas e ideologias diferentes na configuração discursiva, que se aproxima a partir de uma base semântica profunda, possibilitando demonstrar quão parecidos são os sujeitos sociais, independentemente da época e da condição social.
\end{abstract}

Palavras-chave

Corrupção. Decadência. Morte. Fim dos tempos. Folhetos de cordel.

\section{A morte como signo da decadência do mundo}

\author{
Rasgue-se o véo da verdade \\ E fique o mundo convencido, \\ Que todo povo se encontra \\ Completamente illudido, \\ Vão deixar a corrupção \\ Em busca da salvação. \\ Depois de tudo perdido.
}

(JOÃO MARTINS DE ATHAYDE, 1929)

\footnotetext{
* Doutor em Linguística pela Universidade Federal da Paraíba.
} 
Uma suposta decadência do mundo faz com que seja desejado o seu fim, o aniquilamento do que é ruim. A palavra decadência aponta para um sentido de queda, de ruína. É desmoronamento ou invoca instabilidade, tendência à ação da gravidade. Também é associado com o termo corrupção, que acompanha as ideias de contrafação, adulteração do sistema econômico, político, social, moral etc. Da mesma forma que o termo corrupção tende para uma associação semântica com o termo pecado, o termo decadência sugere a morte. Lado a lado, corrupção e decadência validam uma significação de gradação que leva à morte, ou mais precisamente, ao envelhecimento que deságua na morte, a maior e mais temida de todas as quedas.

Esse percurso do envelhecer ao morrer demarca um espaço de tempo de decadência, pela corrupção, pois o envelhecimento é o preço da corrupção, da decadência do homem e do mundo, o que inevitavelmente leva a um desfecho, a morte. Esse fenômeno é representado em datação, temporalidades: nascimento e morte do dia (o nascer do sol e pôr-do-sol); bem como os segundos, os minutos e as horas que comandam, socialmente, o início e o fim de uma semana, o início e o fim de um mês, o primeiro dia e o último dia de um ano, de uma década, de um século, de um milênio e assim por diante.

Paralelamente, o surgir e o ressurgir, fenômeno natural da existência, asseguram a esperança que transborda dos corações prenhes de paixões e geram as comemorações do progresso, da prosperidade. Por outro lado, o término de algo gera a reflexão. É retrospectiva dos acontecimentos passados. Não é festejado por seu valor de finitude, mas pela esperança de um possível novo começo. O fim é o motivo para um investimento na espera/esperança do continuísmo. Espera-se que o fim apague as marcas deixadas pelas corrupções que levaram à decadência. Assim sendo, o antídoto contra a decadência é a inevitável constatação de que há uma esperança na possibilidade de se vencer a morte, a decadência e a corrupção, a partir de um novo começo.

Na Idade Média, mais precisamente no século XIII, a Reforma mobilizou os pensamentos para uma cristianização do termo decadência. A sociedade passou a pensar via mentalidade/religiosidade cristã e as mentalidades se ligaram aos valores de melancolia que o termo decadência desencadeia. Diante de um mundo em decadência, corrompido, deve-se trabalhar ${ }^{1}$ em prol de um progresso espiritual que possa transformar o mundo para melhor. Transformação pela renovação que começa pela Igreja. Essa é a ideia que inspirou Joaquim de Fiori e os seus seguidores, os herdeiros espirituais da Idade Média, que preconizaram a construção de uma Idade de Ouro ou Idade Perfeita; animando-os diante da constatação da decadência e da corrupção desse mundo governado pelo Anticristo e que caminha para uma catástrofe de proporções gigantescas, como eles acreditavam e muitos ainda acreditam.

Assim, como no pensamento platônico, para o sujeito do cordel, a atração pelo prazer anima o desprezo de Deus, afasta o bem da humanidade, atrai o mal, gera violência contra a carne e o pecado da alma. Dessa forma, o homem é conduzido para

${ }^{1}$ O desenvolvimento de uma vida religiosa é, geralmente, concebido como um trabalho de conquista da salvação. 
a corrupção e a desordem, o que gera um caos na vida em sociedade. Nessa perspectiva, fala-se em causas da decadência, é assimilado que a procura pelo prazer leva à perversão, pois faz com que o homem busque sempre retirar o maior proveito do outro, o que gera o esquecimento das coisas espirituais e à perpetuação do mal, do pecado e da decadência.

Numa carta do século III, mais precisamente do ano 410, intitulada Epistula ad Demetrianum, São Cipriano questiona os pensamentos dos sujeitos que, descontentes com o mundo, culpavam a Igreja e o cristianismo pela inflamação do mundo, pela ruína que eles constatavam em suas apreciações dos fenômenos decorrentes da existência, bem como, da condição humana. Le Goff (2006) comenta que, para São Cipriano, a culpa do sol poente não lançar mais raios tão brilhantes não é do cristianismo e sim dos homens, os pagãos, que rendem devoção aos deuses falsos, esquecendo ou negando admirar e louvar o único Deus verdadeiro. No mesmo ano, Santo Agostinho encarregou-se de escrever "cartas", verdadeiros sermões lançados, também, contra os pagãos, que insistiam em culpar a Igreja, os imperadores cristãos e o cristianismo pelos problemas que assolavam o mundo naquela época, em particular, Roma, que foi tomada e saqueada pelos visigodos de Alanico, no ano de 410. Logo, esses abalos foram associados pelos cristãos aos sinais do fim dos tempos, o que foi sendo disseminado e tomado como uma resposta aos modos de vida dos não crentes. Os pagãos foram apontados pelas mídias/escrituras que circulavam como sendo os verdadeiros responsáveis pelo caos vivido por todos. Tomou-se uma postura de avaliação dos fatos, a partir da escatologia.

Passou-se, então, a não mais temer esses acontecimentos e sim aceitar a decadência do mundo como uma prova da necessidade de se investir numa renovação, na espera e na construção espiritual da cidade de Deus. Dessa forma, concebe-se uma lógica judaico-cristã de que assim como a desobediência gerou o pecado, que estava levando o mundo à sua decadência e que os homens já constatavam a decadência gerada pelo pecado como estando em um grau bastante elevado. Nessa perspectiva, os sofrimentos humanos foram encarados como julgamentos de Deus contra os atos humanos, além de serem postos como constatação da vigília de Deus as ações humanas e os sinais da proximidade do Juízo Final.

Essa era, inclusive, a ideia agostiniana de conceber o mundo, o que fez com que ele escrevesse cartas e sermões culpando o homem pelo mal que o próprio homem experimentava. Para ele, Deus é julgamento e o homem é sofrimento. Um processo de causa e efeito pela constatação da "verdade" divulgada pela Igreja e escriturada em gênero epistolar que conduzia o pensamento de Agostinho e Cipriano.

\section{Formas de declínio ou decadência}

Há várias formas de declínio ou decadência. Peter Burke (1976, p. 138) fala em decadência cósmica, moral e religiosa. A primeira tem a ver com a ideia de velhice do mundo. É o que leva muitos religiosos a empreenderem uma marcha rumo ao fim do mundo. Nessa concepção de declínio, são criadas imagens que buscam fazer/trazer sentido, a partir de um valor que impõe uma velhice do mundo. 
Assim sendo, a Terra e todo o universo se encontrariam num declínio total. Nessa perspectiva, unem-se os declínios da natureza ao do universo, em que Céu e Terra se mostram em profunda desarmonia cósmica. Surgem, então, na Terra, desertos mortificantes ou chuvas diluvianas, ora o mar engole o deserto ora é desertificado ("o sertão vai virar mar e o mar vai virar sertão", como propunha Antonio Conselheiro).

João Martins de Athayde (sem local e data) no folheto O fim do mundo, nos dá uma ideia de como é a visão profetizada pelo poeta visionário:

\author{
O futuro cataclismo \\ Não durará muitos dias \\ Ele vem muito perto \\ E nós teremos de certo, \\ A chegada do messias \\ As chuvas vão devorando \\ O que existe na terra \\ Transformando-se em tudo em cinzas \\ Como no campo de guerra \\ Ninguém suporta o mormaço \\ Os coriscos cortam o espaço \\ Os vulcões surgem na serra
}

Há ainda a luz do céu escurecendo, diminuindo a possibilidade de vida na Terra; ou se intensificando, aquecendo e queimando a vida, pondo um basta na possibilidade de existência. Daí, surgem mazelas na epiderme, feridas causadas pelo brilho e ardor intenso do sol que queima a pele humana, tirando-Ihe a vida. Enfim, a desarmonia cósmica, o que promove o desarranjo na vida natural no Planeta Terra, para a maioria dos ambientalistas, será a causa do extermínio da vida humana na Terra.

Por outro lado, a decadência moral se configura no comportamento da humanidade, refletindo-se, por exemplo, na moda, isto é, nos hábitos, configurados em costumes, que são, muitas vezes, associado ao burlar das regras e condutas impostas pela sociedade. Estando associado à luxúria ou ao apego pela riqueza material; além dos vícios, da prostituição, das festas não religiosas, o que é associado ao abandono do sagrado, estando em desarmonia com os costumes dos primeiros cristãos, os chamados cristãos verdadeiros.

No folheto $A$ vinda de Jesus e a nova Jerusalém, de Severino Paulo da Silva, Juazeiro do Norte, 1960; há um aviso/intimidação para os sujeitos infiéis aos mandamentos de obediência aos preceitos religiosos cristãos:

Obedeça os mandamentos

Ou tudo estará perdido

[...]

Quem ama a Deus, com fé

Alcançará o perdão 


\footnotetext{
E quem não amar com fé Alcança a condenação Vai viver com satanás Dando suspiro voraz Dentro da escuridão [...] Deus manda o fogo sagrado E deixa ele queimando Em cinza da terra dura

[...]

O homem pede arrogo A terra pegará fogo Que fica toda tostada [...] Porém antes que o fogo Toste a fasse da terra Virá 3 anos de seca

[...] Assim que passar o fogo Ruim não fica ninguém Deus faz a santa aliança Da nova Jerusalém.
}

Em seguida, no folheto O fim do mundo, de Sebastião T. de Souza, sem local, sem data; o sujeito do cordel aconselha/avisa:

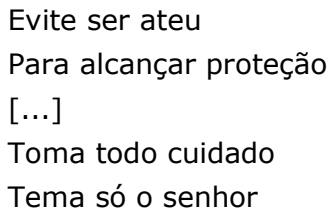

A necessidade desse lembrete/ameaça remete ao afastamento das boas condutas ou virtudes espirituais: avareza, orgulho, falta de piedade, hipocrisia, ignorância, indisciplina frente às personalidades religiosas, falta de caridade, falta de humanidade e a intolerância às decisões da Igreja, além do desrespeito às autoridades religiosas.

Como expresso no folheto O Rapaz que virou bode porque profanou de Frei Damião, de José Costa Leite, sem local, sem data; em que o rapaz foi transformado em cabra como forma de castigo pelo não respeito, aceitação e devoção ao santo reverenciado pelo catolicismo popular: 


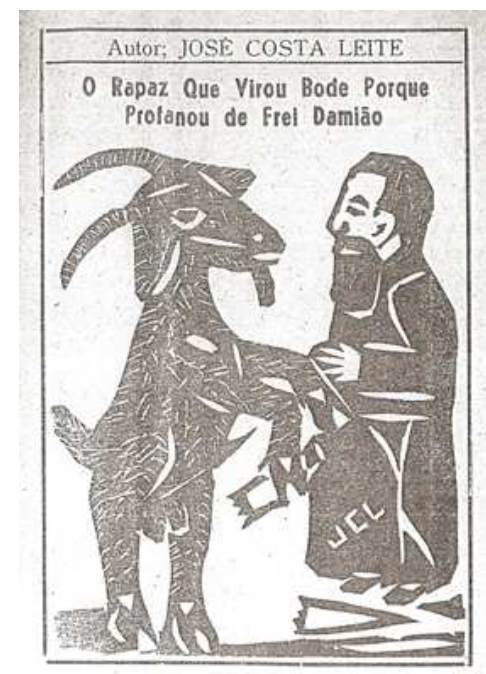

Xilogravura 1 - Capa do folheto “O Rapaz que virou bode porque profanou de Frei Damião”.

O conjunto dessas decadências humanas leva à efetivação ou cumprimento das profecias de fim do mundo, acontecimentos que são descritos pela escatologia apocalíptica de diversas religiões, em destaque as judaico-cristãs.

Dessa forma, a decadência vai sendo traduzida pelo poeta em corrupção, crise, carestia e inflação; denunciados e estampados nas capas dos cordéis:

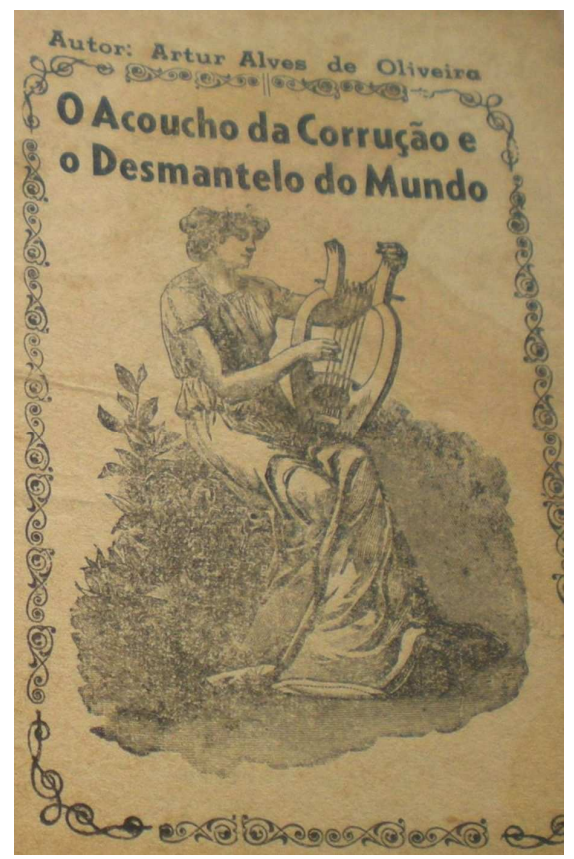

Figura 1 - Capa do folheto "O acoucho da corrução e o desmantelo do mundo", de Artur Alves de Oliveira, sem local, sem data

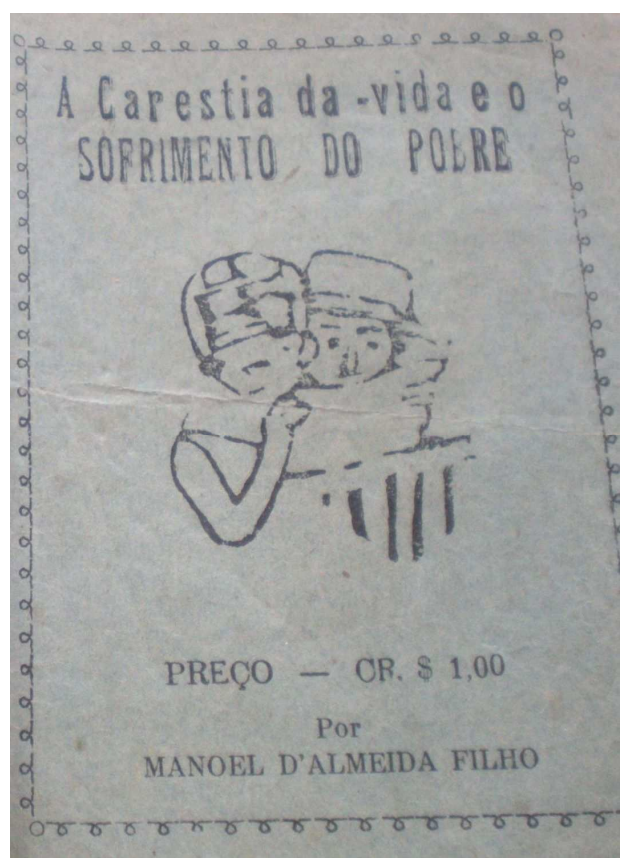

Xilogravura 2 - Capa do folheto "A Carestia da vida e o sofrimento do pobre", de Manoel D'Almeida Filho, sem local, sem data. 


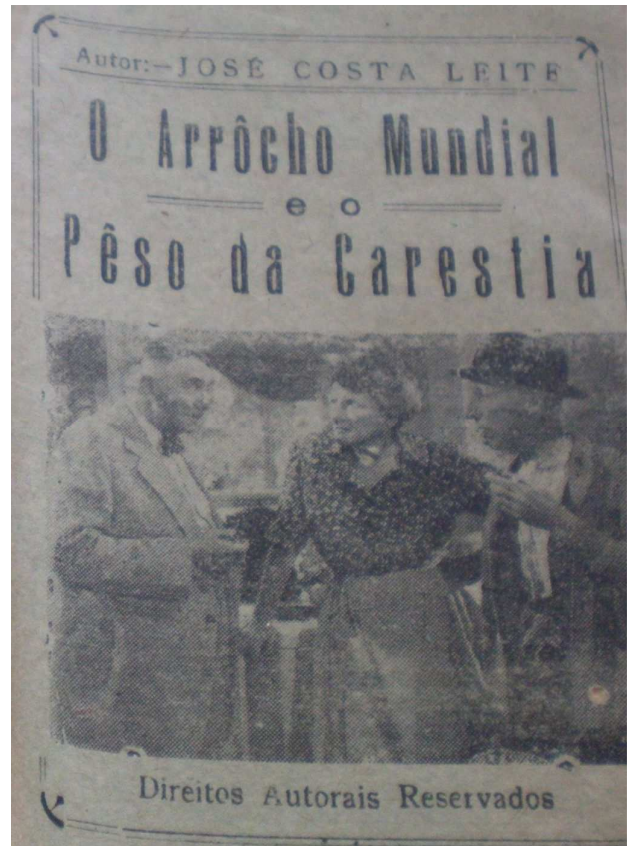

Figura 2 - Capa do folheto "O arrôcho mundial e o pêso da carestia", de José Costa Leite, sem local, sem data

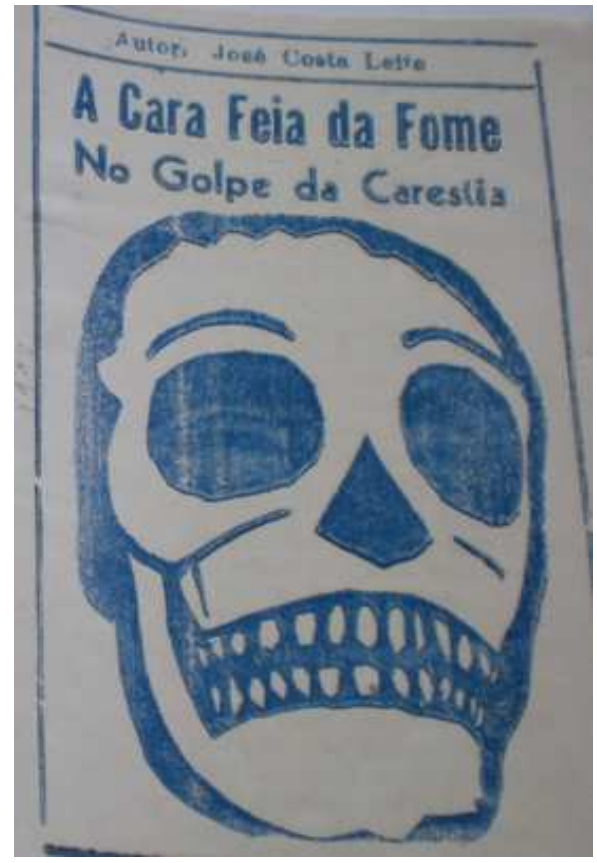

Xilogravura 3 - Capa do folheto "A Cara feia da fome: no golpe da carestia", de José Costa Leite, sem local, sem data.

Neste contexto, a inflação é figurativizada por uma cobra de duas cabeças, que na xilogravura da capa do folheto $A b c$ de Delfim Neto e o problema da inflação, de Rodolfo Coelho Cavalcante, Salvador/Bahia, 1982; duela com uma senhora/bruxa/xamã, que tenta combater ou domar esse mal que assola a comunidade produtora dessas vozes:

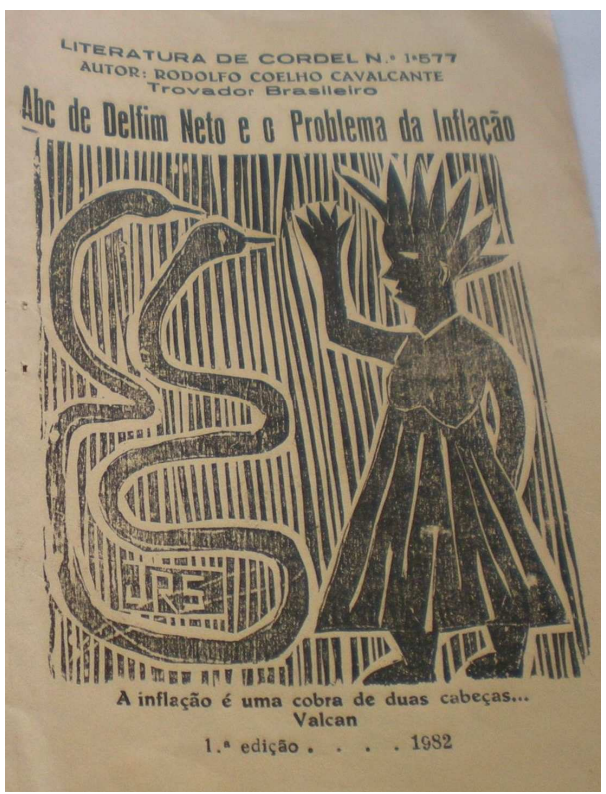

Xilogravura 4 - Capa do folheto "Abc de Delfim Neto e o problema da inflação". 
Curiosamente, a carestia que golpeia o homem que sofre com a fome é personificada na figura de uma mulher gigante (analogia com o gigante Golias, descrito na Bíblia), a qual é cobrada pelo caos do mundo. Como estampa o folheto $O$ clamor da carestia, de João Vicente Emiliano, Vitória de Santo Antão/Pernambuco, sem data:

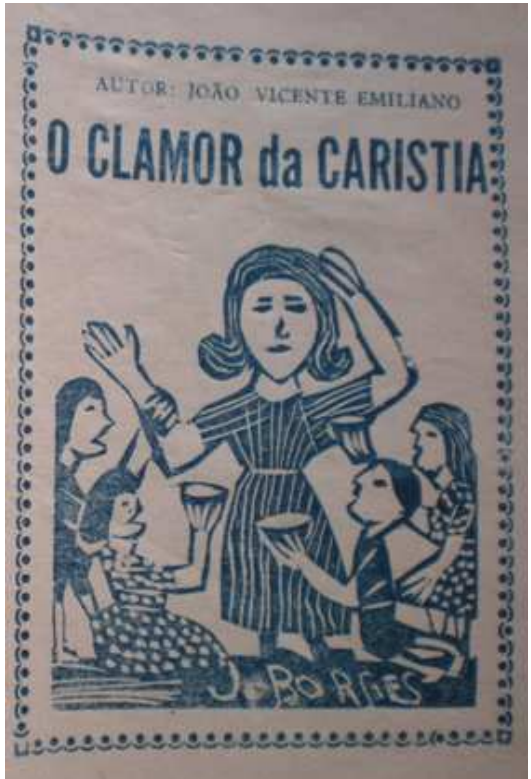

Xilogravura 5 - Capa do folheto "O clamor da carestia".

Em Os clamores da carestia, de Expedito F. Silva, sem local, sem data; a mulher/a carestia embala a sua criatura. O homem é posto no colo da carestia, sendo o seu nascimento no mundo já uma forma de castigo advindo do pecado humano:

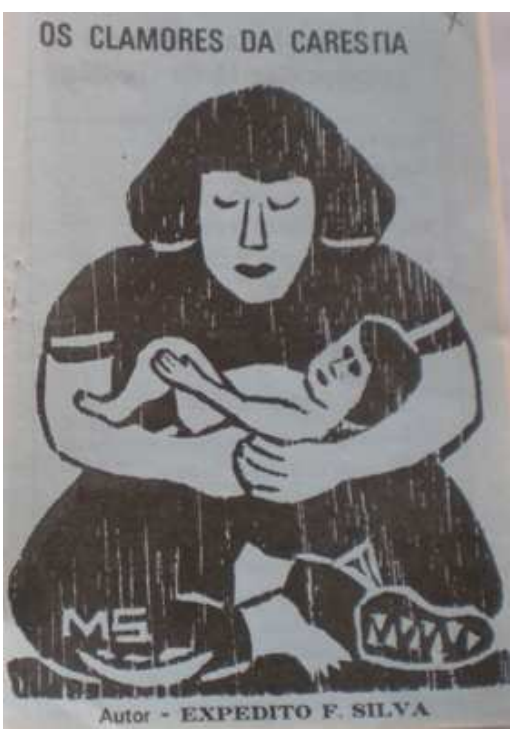

Xilogravura 6 - Capa do folheto "Os clamores da carestia". 
No folheto Hoje só tem carestia, samba, moda e corrução, de João Vicente Emiliano, Pernambuco, sem data; a mulher/carestia é desenhada numa performance de perversão/luxúria, em que veste saia curta, enquanto o homem é posto como trabalhador ou um sofredor retirante:

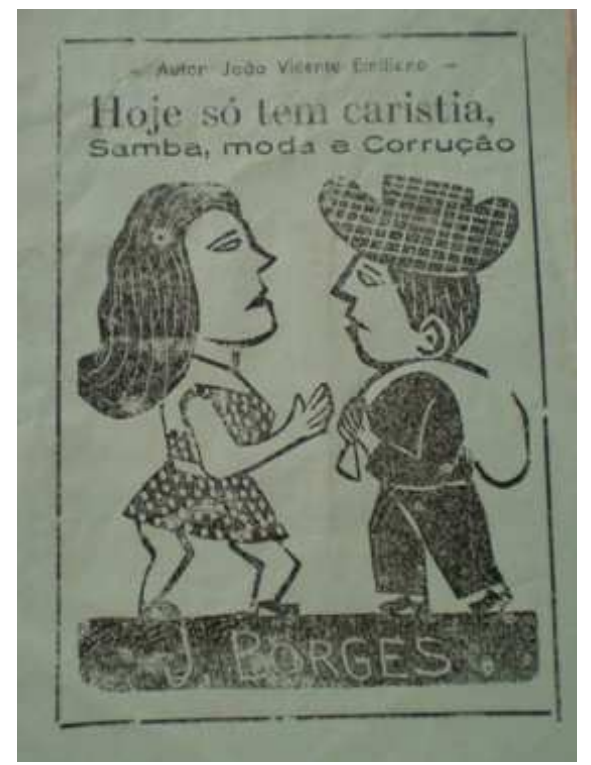

Xilogravura 7 - Capa do folheto "Hoje só tem carestia, samba, moda e corrução".

A canção de 1960, Brotinho sem juízo, composta por Carlos Imperial e interpretada por Roberto Carlos, no início de sua carreira, dá o tom da imagem da mulher que o cordel analisado atualiza. A mulher empreende uma performance de sedução e encanto em que o homem, novamente, é apresentado como sendo uma vítima das armadilhas postas pela mulher para desencaminhar o homem de sua conduta reta:

Brotinho toma juízo

Ouve o meu conselho

Abotoa esse decote

Vê se cobre esse joelho

Pára de me chamar

De meu amor

Senão eu perco a razão

Esqueço até quem eu sou

Brotinho não me aperte

Quando comigo dançar

Tira a mão de meu pescoço

Não tente seu rosto colar

Pára de beliscar a minha orelha

Porque se o sangue subir

Eu faço o que me dá na telha 
E você vai se dar mal

Vai, vai haver um carnaval.

Brotinho não custa nada

Um pouquinho esperar

Um dia com véu e grinalda

Certinha você vai casar

Então você vai me agradecer

Porque eu fui tão bobinho com você

Assim, a decadência cósmica é uma decorrência da decadência moral ou humana, além da religiosa. Consequentemente, a decadência moral é posta como sendo motivada pela decadência cósmica, que leva as mulheres a usarem roupas escandalosas, o que é motivado pelo calor excessivo, causado pelo aquecimento solar nas regiões tropicais. Razão que faz com que sejam adotadas roupas curtas, pouca roupa ou quase nenhuma, mas que é interpretado ou percebido pelo sujeito vigilante dos hábitos religiosos como sendo um abandono à boa conduta, sendo uma falta de moral, um pecado, prova da decadência do mundo. Como denuncia o folheto $O$ escandalo do banho da beira do mar, de João Severino da Silva, sem local, sem data:

No folheto $O$ Bataclam moderno e as moças semi-núas, de João Martins de Atayde, Recife, Pernambuco, 1927; temos uma amostra dessa representação da suposta falta de moral das mulheres, já no início do século passado:

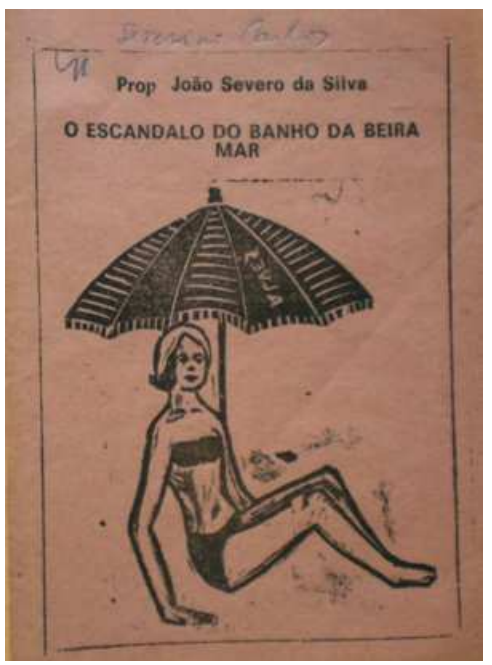

Xilogravura 8 - Capa do folheto "O escandalo do banho da beira do mar".

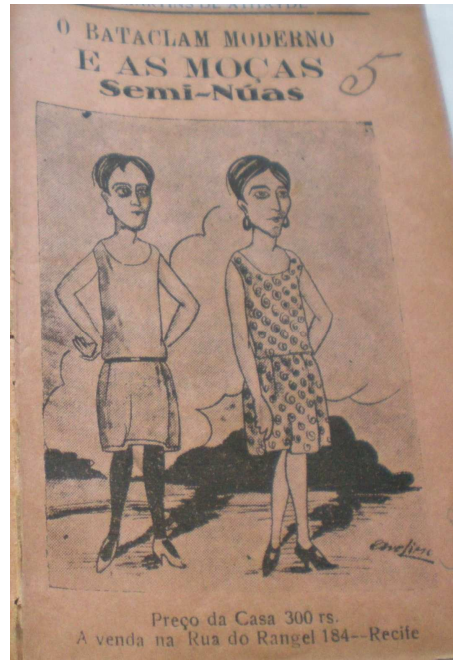

Figura 3 - Capa do folheto "O Bataclam moderno e as moças semi-núas".

É o que pode ser observado nas capas dos folhetos selecionados em seguida, como sendo representações da "corrução" no mundo, de um progresso que é decadente e que empurra o homem para baixo, para a queda, para a morte: 


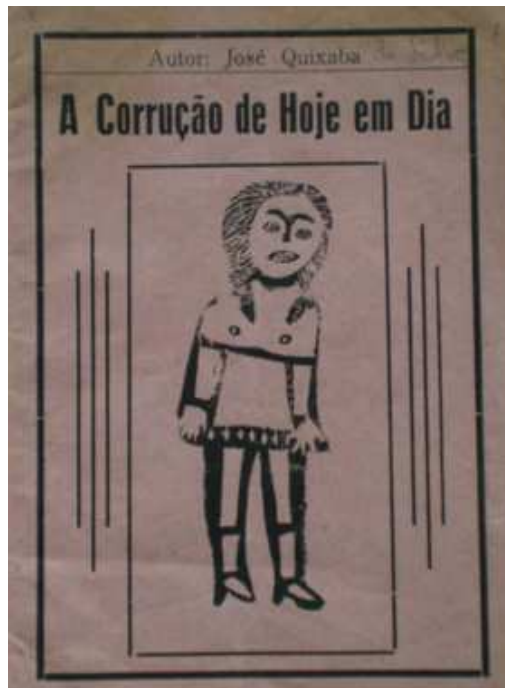

Xilogravura 9 - Capa do folheto "A Corrução de hoje em dia", de José Quixaba da Silva, sem local, sem data.

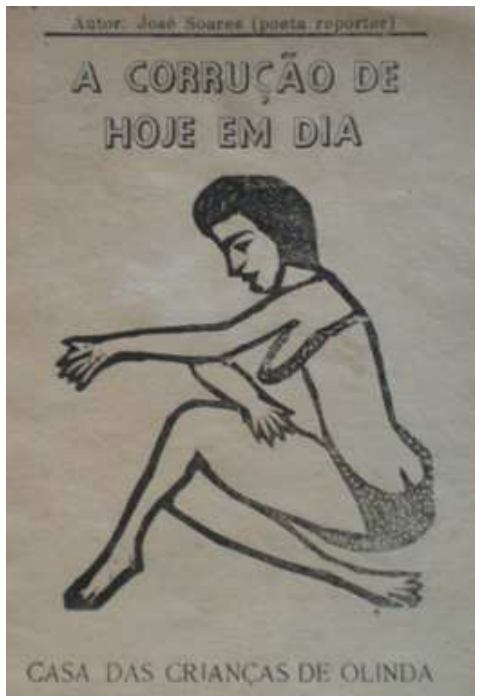

Xilogravura 10 - Capa do folheto "A Corrução de hoje em dia", de José Soares, Pernambuco, sem data.

Note na primeira capa que a mulher possui feições pesadas ou esdrúxulas, enquanto na segunda capa ela usa roupas de banho menores que as proporções do seu corpo, deixando revelar algumas partes, o que afeta a censura do sujeito do cordel.

Nas imagens que se seguem, reafirma-se a figurativização de provocação da mulher frente à visão preconceituosa do poeta popular. A mulher posa como sendo um objeto de desejo, "usada" pelo mal para desviar o homem do seu caminho de retidão. Mais uma vez, o biquini é posto em destaque como sendo uma ferramenta de sedução da mulher:

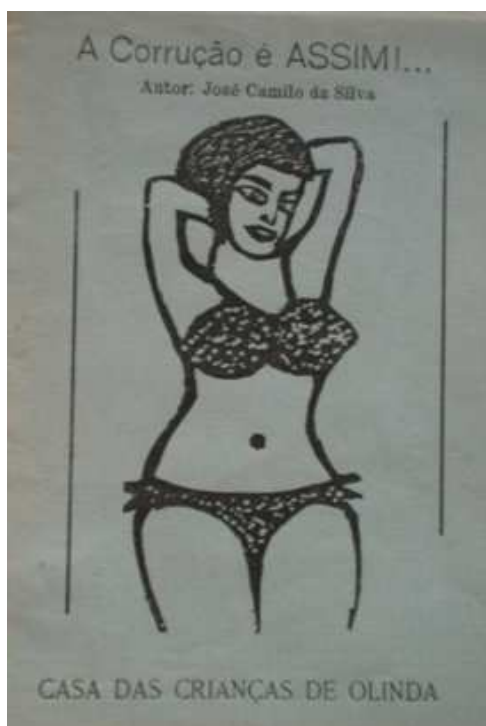

Xilogravura 11 - Capa do folheto "A Corrução é assim!.."., de José Camilo da silva, Pernambuco, sem data.

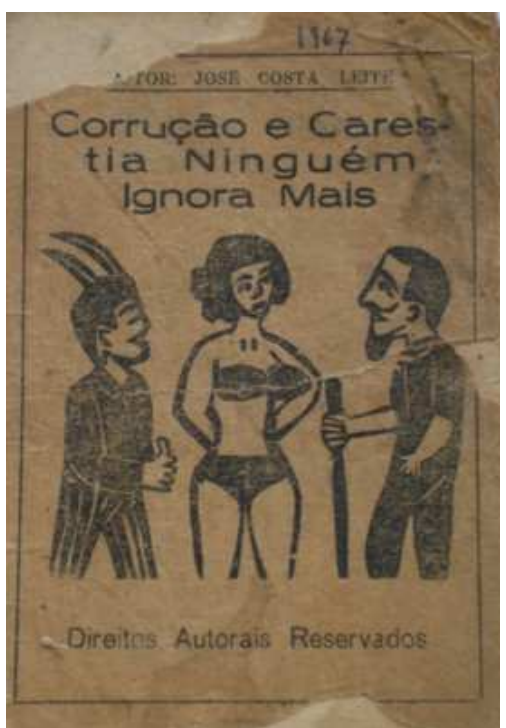

Xilogravura 12 - Capa do folheto "Corrução e carestia ninguém ignora mais", de José Costa Leite, Pernambuco, 1967. 
Em A História da mulher, de Marco di Aurélio, Pernambuco, 2005; um exemplo de folheto que trata do tema do fim dos tempos de forma implícita; a mulher é posta como responsável pelo "desmantelo" do mundo. Nele, observamos as formas e as cores que são combinadas para compor a imagem da mulher num cenário de corrupção e decadência que move a imaginação dos sujeitos do cordel, mediante paixões e angústias que surgem da experiência vivida em tempos de modernidade julgada decadente:
Na história se perdeu
dizendo ser heresia
a verdadeira origem
na mulhee sua histeria
que não suoprtando mais
manifesta o satanás
para tentar voltar o dia
O tempo não volta mais
e ela não percebeu
o paraíso se foi
o casal foi quem perdeu
hoje são inquilinos
agüentando seus meninos
cada qual um Zebedeu

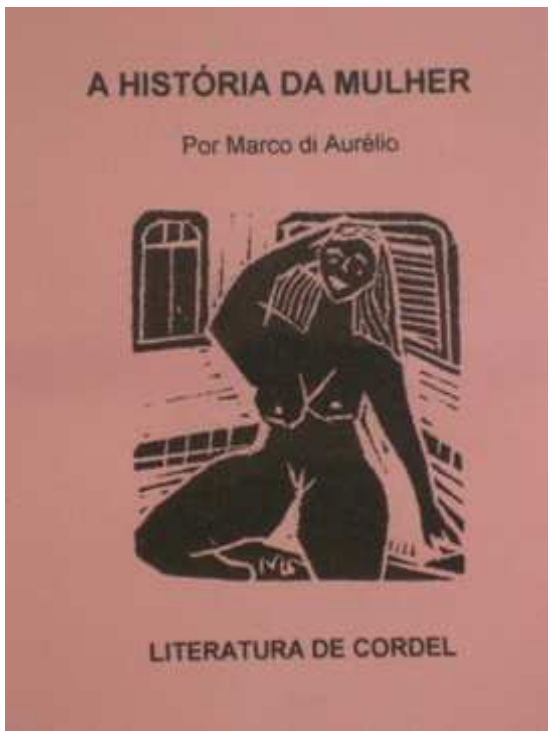

Xilogravura 13 - Capa do folheto "A história da mulher".

Neste caso, a mulher é pintada de preto, cor que no Ocidente remete ao sombrio, nefasto, lado do mal, em oposição ao branco, considerado limpo, lado do bem. A mulher posa nua para a capa de um folheto que pretende contar "A história da 
mulher", que "manifesta o satanás", comentário que comprova o forte teor de preconceito sofrido pela mulher no universo de produção desses folhetos.

Gradualmente, a morte vai se impondo na sociedade temerosa pela corrupção e declínio advindos do poder da carestia e da suposta inflamação/inflação da mulher. Neste cenário, uma narrativa se impõe e arranja as imagens postas nas capas das xilogravuras, permitindo fazermos a leitura de um homem que caminha rumo à morte, pois enforcar-se é uma solução para se fugir do peso que a carestia põe na vida do homem. Sendo esta uma forma de decadência legitimada na sociedade produtora dessas vozes.

Ironicamente, numa fazenda chamada fartura, como assinalado no final da capa do folheto As consequências que têm o roubo e a carestia, de Antônio Batista Romão, Paraíba, 1966; o número 666 (sinal da Besta descrita no livro do apocalipse) nos chama a atenção pela data 6-6-66 posta, supostamente, pelos proprietários "compradores" do folheto².

Nele, há a imagem de um homem numa performance de queda (perda da guerra/batalha contra a carestia), pondo uma corda no pescoço, elaborando/ameaçando um suicídio:

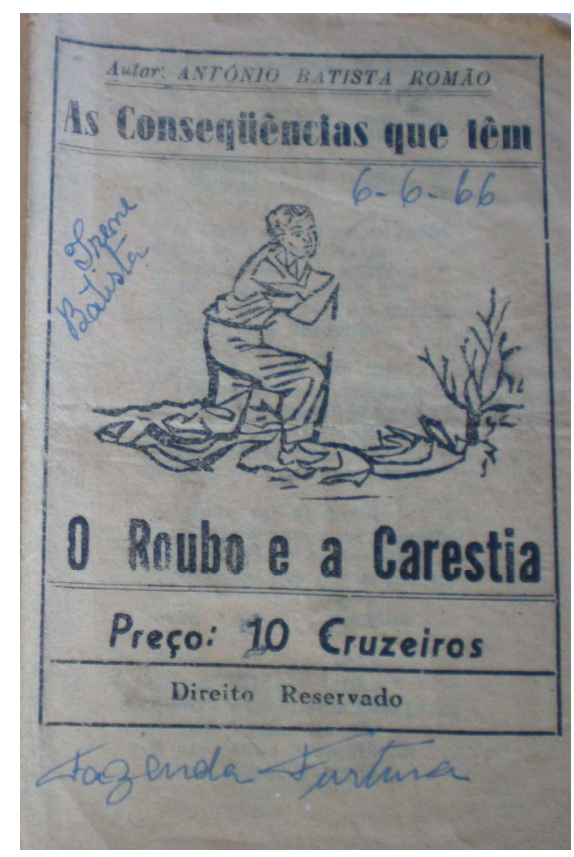

Xilogravura 14 - Capa do folheto "As consequências que têm o roubo e a carestia".

No segundo folheto, O horror da carestia, de Vicente Vitorino Melo, Paraíba, sem data; verificamos o alinhamento desta rede de conexões de sentidos que tematizam acerca da morte do homem, vitimado pelos apuros vividos por ele na sociedade sob a

\footnotetext{
${ }^{2}$ Cremos que as escritas, em caneta, postas na capa do folheto em destaque sejam de duas pessoas diferentes, já que a caligrafia que assinala os enunciados "Irene Batista" e "6-6-66" têm um traçado gráfico e o enunciado "Fazenda Fartura" tem outro.
} 
influência da carestia, e avaliada como decadente. Ele caminha para o seu fim, ironicamente, ascende para a queda, porque o desespero o faz crer que morrer para um mundo de horror e carestia é uma vitória contra o sofrimento:

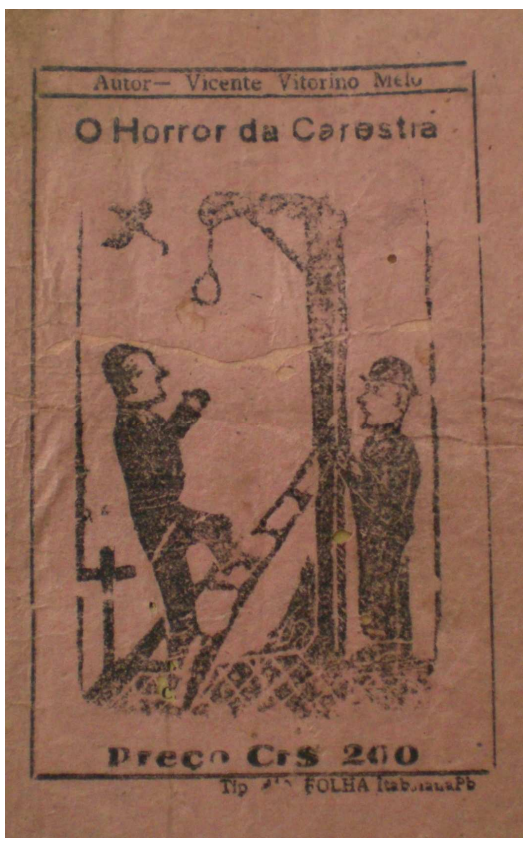

Xilogravura 15 - Capa do folheto "O horror da carestia".

Finalmente, no terceiro folheto, como o título do cordel anuncia, $O$ homem que foi se enforcar com medo da carestia, de José Costa Leite, sem local, sem data; há a confirmação/efetivação do suicídio da narrativa que simboliza a morte humana em favor da decadência:

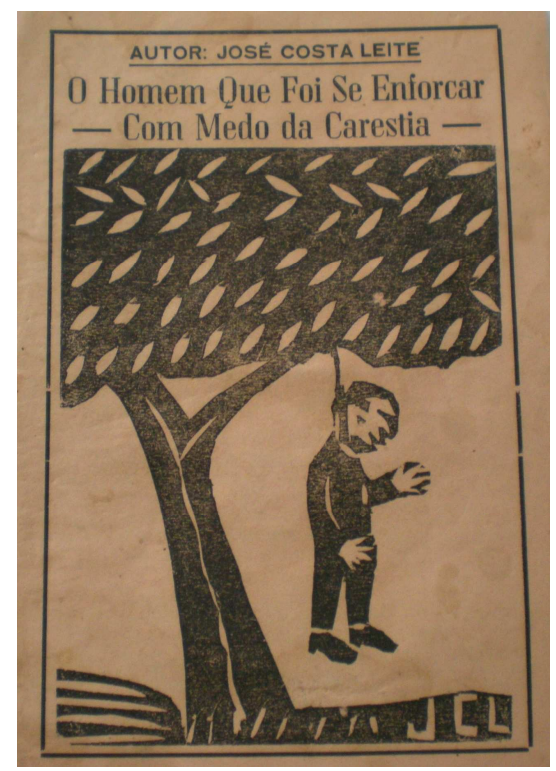

Xilogravura 16 - Capa do folheto "O homem que foi se enforcar com medo da carestia". 


\section{Considerações finais}

Sob uma linguagem escatológica, os discursos que dão as coordenadas de caminhada aos sujeitos religiosos (a utilização de certas práticas e outra não) e que fundamentam a produção dos gêneros textuais/discursivos que tematizam acerca do fim dos tempos são, essencialmente, instauradores de um plano atemporal/ahistórico. Isto faz com que o discurso do fim dos tempos rompa com o pacto racional entre tempo/história, eliminado a lógica binária de uma linearidade da história assentada em sucessivas idas e vindas de homens que entram na história e saem da história uma única vez através do nascimento e da morte.

A partir desse recurso, utilizam-se enunciados que ilustram um mundo em plena decadência, exemplo de poluição da alma humana, o que invoca a plenitude da ocorrência de um fim, agendado para acontecer em breve. Por isso, fala-se na conversão do pecador em cristão como forma de salvação. O evangelho dos folhetos demonstra que a salvação é certa para aqueles que todo o tempo se mostraram fiéis a justiça divina. Neles, figura a ideia que só os cristãos terão a salvação garantida.

As causas que levam a produção desses discursos são óbvias, o povo nordestino é essencialmente religioso. E tamanha religiosidade decorre das condições de vida enfrentadas pelos sujeitos desta região. Creem que as paixões humanas levaram este mundo a decadência que se encontra. Por isso, o apelo ao exemplo do que gerou a decadência do mundo, o que faz do próprio homem exemplo da decadência experimentada.

Cremos que isso é o que produz história, memória. Como o homem descreveria a si próprio e o mundo se não estivesse atento a sua própria sensibilidade? A história humana é a história de civilizações que narraram suas experiências, angústias e paixões, a partir da crença em dias melhores, que se contrapõem aos últimos dias.

Esta é mais uma justificativa do valor que atribuímos a pesquisa ora apresentada. Ela nos faz perceber que não seria possível conhecer os sujeitos dessa região, a não ser pela leitura de suas vozes escrituradas em manuscritos que conhecemos por cordéis. Tais folhetos são antes documentos, monumentos, registros de memórias que permitem observar elementos antes isolados, hoje dialógicos, agrupamento de vozes que ressignificam, em conjunto, aquilo que as pesquisas passadas separou, dissecou e retirou a vida.

Diferentemente do que muitos folcloristas sustentam, o cordel é memória medieval adaptada para exercer a movência dos sentidos que animam o espaço em que atuam os sujeitos nordestinos. São vozes escrituradas para cavalgar no barbante como elo entre tempos fronteiriços. Assim sendo, não dá mais para sustentar a ideia de morte do cordel. Como revelou nossa pesquisa, o cordel fala de morte, mas se mantém em plena produção/atualização/atuação. Renova-se para tematizar acerca de reinos e universos proféticos de ação escatológica, que fertilizam a imaginação humana e sustentam /substanciam, inclusive, produções televisivas, tais como minisséries e telenovelas. O cordel vive para atualizar o discurso de morte que ronda um mundo ameaçado de queda. 


\section{Referências}

ATAYDE, João Martins de. O Bataclam moderno e as moças semi-núas. Recife/Pernambuco, 1927. 1929. . O fim do mundo (ou Os últimos dias da humanidade). Recife/Pernambuco, O fim do mundo. Sem local, sem data.

AURÉLIO, Marco di. A História da mulher. Pernambuco, 2005.

BURKE, Peter. Tradition and experience: the idea of from Bruno to Gibbon. Daedalus, 1976.

CAVALCANTE, Rodolfo Coelho. Abc de Delfim Neto e o problema da inflação. Salvador/Bahia, 1982.

EMILIANO, João Vicente. Hoje só tem carestia, samba, moda e corrução. Pernambuco, sem data.

O clamor da carestia. Vitória de Santo Antão/Pernambuco, sem data.

FILHO, Manoel D'Almeida. A Carestia da vida e o sofrimento do pobre.

LE GOFF, Jacques \& SCHMITT, Jean-Claude. Dicionário temático do ocidente medieval I e II. São Paulo: EDUSC, 2006.

LEITE, José Costa. A cara feia da fome: no golpe da carestia. Sem local, sem data. . Corrução e carestia ninguém ignora mais. Pernambuco, 1967.

data. . O Rapaz que virou bode porque profanou de Frei Damião. Sem local, sem . O arrôcho mundial e o pêso da carestia. Sem local, sem data.

. O homem que foi se enforcar com medo da carestia. Sem local, sem data.

MELO, Vicente Vitorino. O horror da carestia. Paraíba, sem data.

OLIVEIRA, Artur Alves de. O acoucho da corrução e o desmantelo do mundo. Sem local, sem data.

ROMÃO, Antônio Batista. As consequências que têm o roubo e a carestia. Cajazeira/Paraíba, 1966.

SILVA, Expedito F. Os clamores da carestia. Sem local, sem data.

SILVA, João Severino da. O escandalo do banho da beira do mar. Sem local, sem data.

SILVA, José Camilo da. A Corrução é assim!... Pernambuco, sem data.

SILVA, José Quixaba da. A Corrução de hoje em dia. Sem local, sem data.

SILVA, Severino Paulo da. A vinda de Jesus e a nova Jerusalém. Juazeiro do Norte, 1960.

SOARES, José. A Corrução de hoje em dia. Pernambuco, sem data.

SOUZA, Sebastião T. de. O fim do mundo. Sem local, sem data. 


\section{Title}

Corruption and decadence: updating death in the folheto de cordel

\section{Abstract}

Two are the kinds of unrest that move human curiosity; from where we came and to where we will go. One expects to know how was the beginning (cosmogony), how thing began to happen; and one expects to know our end (escatology), the moment, which signals the end of humanity. The present paper analyzes the result of a research aiming to demonstrate that the cordel, as a medieval writing in the current days, narrates and turns into discourse themes that are always present in the social memory. This research found that the folhetos update, very frequently, the theme of death and of the end of times, connecting differing subjects, epochs and ideologies in the discursive configuration, which are brought closer from a deep semantic basis, thus making possible to demonstrate how similar are the social subjects, no matter the epoch, nor the social condition.

\section{Keywords}

Corruption. Decadence. Death. End of times. Folhetos de cordel.

Recebido em 15.05.2011. Aprovado em 11.07.2011. 